\title{
Strengthening ICT competencies in Higher Secondary Education teachers to improve teaching practice in the health emergency of Covid 19
}

\section{Fortalecimiento de competencias TIC en profesores de Educación Media Superior para mejorar la práctica docente en la emergencia sanitaria del Covid 19}

GÓMEZ-CAMPOS, Sinahí Gabriela $\dagger^{*}$, GRANADOS-MAGAÑA, Javier Alejandro, ZEPEDAMARTÍNEZ, Gabriel and FREGOSO-HERNÁNDEZ, Carlos Baltazar

Universidad Autónoma de Nayarit

ID $1^{\text {st }}$ Author: Sinahí Gabriela, Gómez-Campos / ORC ID: 0000-0002-4580-6230

ID $1^{\text {st }}$ Coauthor: Javier Alejandro, Granados-Magaña / ORC ID: 0000-0002-2940-4573

ID $2^{\text {nd }}$ Coauthor: Gabriel, Zepeda-Martínez / ORC ID: 0000-0003-0703-7351, Researcher ID Thomson: B-5649-2019, CVU CONACYT ID: 257469

ID $3^{\text {rd }}$ Coauthor: Carlos Baltazar, Fregoso Hernández / ORC ID: 0000-0002-3475-9627

DOI: $10.35429 /$ JITC.2020.11.4.1.7

Received March 10, 2020; Accepted June 30, 2020

Abstract

SARS-CoV-2 has brought enormous challenges and challenges to the global education system. The crisis has demonstrated the vulnerability of current educational models, their rapid and accelerated spread throughout the world has caused an unprecedented impact on the multidimensional development of the population. This brought as a possible solution the implementation and accelerated adaptation of working at a distance with approaches oriented to the use of Information and Communication Technologies (ICT), The project proposed as an objective to evaluate the knowledge and skills management of upper secondary teachers (northern part of the state of Nayarit), before and during the COVID19 pandemic. The study is a non-experimental descriptive transectional study with a sample of teachers from the three Preparatory Academic Units of the UAN. A nonprobability convenience sampling was used using two predesigned questionnaires through the Google Forms platform, one at the beginning and the other at the end. With this project it was detected that no teacher uses digital tools at the beginning for online classes.

Covid 19, Teacher training, Distance education, Information and Communication Technologies

\begin{abstract}
Resumen
El SARS-CoV-2 ha traído enormes retos y desafíos al sistema educativo mundial. La crisis ha demostrado la vulnerabilidad de los modelos educativos actuales, su rápido y acelerado esparcimiento en todo el mundo ha causado un impacto sin precedentes en el desarrollo multidimensional de la población. Esto trajo como posibilidad de solución la implementación y adaptación acelerada de trabajar a distancia con enfoques orientados al uso de las Tecnologías de la Información y Comunicación (TIC), El proyecto planteó como objetivo evaluar el conocimiento y manejo de competencias de los docentes de media superior (zona norte del estado de Nayarit), antes y durante la pandemia de COVID-19. El estudio es no experimental descriptivo transeccional con una muestra de docentes de las tres Unidades Académicas Preparatorias de la UAN. Se utilizó un muestreo no probabilístico por conveniencia empleando dos cuestionarios prediseñados a través de la plataforma Google Forms, uno al inicio y el otro al final. Con este proyecto se detectó que ningún docente maneja herramientas digitales al inicio para las clases en línea.
\end{abstract}

Covid 19, Formación de docentes, Educación a distancia, Tecnologías de la Información y Comunicación

Citation: GÓMEZ-CAMPOS, Sinahí Gabriela, GRANADOS-MAGAÑA, Javier Alejandro, ZEPEDA- MARTÍNEZ, Gabriel and FREGOSO-HERNÁNDEZ, Carlos Baltazar. Strengthening ICT competencies in Higher Secondary Education teachers to improve teaching practice in the health emergency of Covid 19. Journal of Information Technologies and Communications. 2020. 4-11:1-7

\footnotetext{
* Correspondence to Author (e-mail: sinahi.gomez@uan.edu.mx)

$\dagger$ Researcher contributing as first author
} 


\section{Introduction}

The rapid and alarming spread of COVID 19 has had an exceptional impact on the development of education around the world. In the opening reasoning of the Director General of the World Health Organization (WHO) at the press conference on COVID-19 on March 11, 2020, it was noted that it was spreading from person to person in all parts of the world, being considered and declared as a pandemic through the World Health Organization (WHO, 2020).

The consequences that we have seen are that governments will speak out in favor of welcoming and implementing health emergency measures, confinement and social isolation to prevent the spread of the virus nationally and internationally. The effects within education have been devastating in various areas of the lives of students, as well as teachers, also from the field of physical and mental health to economic, cultural and social, according to data from organizations such as the WHO (2020), the Pan American Health Organization (PAHO, 2020), the Economic Commission for Latin America and the Caribbean (ECLAC, 2020) and World Vision International (2020).

As the COVID-19 pandemic moves across the world, it becomes more necessary to understand and address the educational needs of children and youth during this global health crisis. It is precisely on this level that the governments adopted measures to suspend activities of face-to-face classes, complying with the recommendations of the health sector in order to avoid the contagion and spread of the virus. It should be noted that according to UNESCO figures (2020a), nearly 1.2 billion students around the world have been affected by the closure of schools and universities due to the COVID-19 outbreak.

The unexpected breakdown of regular classroom activities brought as the only immediate solution alternative, the implementation of the distance modality in order to give continuity to the teaching-learning process. This has implied the adaptation of approaches oriented to the use of Information and Communication Technologies (ICT). Without a doubt, it has been a great institutional and human effort to participate in this sudden process of modification from one classroom modality to another characterized by the nonpresence of the teaching act.
However, questions arise from the teacher's perspective about the preparation and prior knowledge in the use of digital resources and tools to develop a non-face-to-face class, but it is also worth asking how the teaching-learning activity is being developed under the non-face mode. With the evolution of the internet and information and communication technologies in the last decade, new trends have emerged in technology-mediated education. On the other hand, students have grown up with technology around them, which has brought as a consequence that they rely on it to carry out any academic activity.

This has forced the creation of new teaching modalities, in such a way that traditional teaching is no longer the only feasible one; distance education and combined education (b-learning) have been positioned as new teaching alternatives. Likewise, the democratization of information has allowed the appearance of mass free online courses (MOOC), as well as the appearance of Educational Platforms or Learning Management Systems (LMS), in addition to new teaching approaches such as Inverted Learning and its practical application called Flipped Classroom.

The use of ICT in Higher Secondary Education is a topic that has been investigated by several authors; They state that despite the fact that it has been proven that the use of ICT benefits students in various ways such as motivation, availability of materials and activities, increased productivity, and improved understanding; teachers have not been trained and few do, so the impact they cause is low (Bauer and Kenton, 2005; Cuban and Krikpatrick, 2001; Kozma, 2003; Robertson, 2003).

According to documents from the United Nations Organization for Science, Education and Culture (UNESCO), for the year 2016 a strategy of integration of Communication and Information Technologies (ICT) in the teachinglearning process is applied globally; This would allow access to education to be universal, for there to be greater equality for instruction, for teaching to be more effective, and it also promotes the professional development of teachers, among other factors that affect the educational development of a center, a region or a country. (UNESCO, 2016). 
Having trained teachers who have knowledge and skills in Educational Technology is important, in order to achieve meaningful learning through Virtual Learning Environments (VLE) that are available to the student anywhere and at any time, materials and learning activities. Said data for the indicated year reflect a reality of inequity of access to a possible distance modality using digital tools. Although the forceful action of the government to make access possible through agreements with mobile phone and internet operating agencies in order to guarantee and facilitate optimal access for the development of teaching activity, one might also wonder if the characteristics of connectivity are those required to use digital tools in the absence of classes.

As a precedent in the region is the report on the conditions of teaching work in the context of social, preventive and compulsory isolation ordered by governments around the world. The objective of this research was to know the way in which the non-face-to-face teaching processes before and during the quarantine impacted teachers in the northern part of the state of Nayarit

In a study on educational responses to the COVID-19 pandemic as a result of the results of a rapid assessment carried out in its member countries, between March 18 and 27, 2020, by the Organization for Economic Cooperation and Development (OECD , 2020) highlights that the majority of responses focus on establishing the challenges in the availability and management of technological infrastructure, some challenges in the lack of support from parents in learning at home and the lack of capacity and will of teachers to apply adaptations to the changes required by the crisis situation.

The study also notes that a significant percentage of respondents see that the unexpected positive educational outcomes of the changes caused by the crisis include the introduction of technologies and other innovative solutions and an increase in the autonomy of students to manage their own learning..

Equally relevant are the recommendations to guarantee the continuity of learning and the application of technologies for the development of virtual activities during the closure of schools in the midst of the pandemic established by UNESCO (2020b).
Among which it is worth highlighting those related to the application of measures to guarantee access for students, the instruments to create links between schools, parents, teachers and students, the creation of orientation sessions for teachers and students. parents for monitoring and accompaniment, the precision of the duration of the learning units based on the selfregulation skills of the students and the determination of a teaching rhythm consistent with the level of self-regulation and metacognitive skills of the students. These guidelines could be adopted by school institutions in order to adapt and develop the distance learning process contextualized to the particular needs of students.

The study's general objective was to analyze the competence performance of teachers in schools in the north of the state, during the COVID-19 pandemic. As specific objectives, it was established to identify the level of prior knowledge about the application of ICT for the development of non-contact classes, define the status of training and prior preparation for the development of non-contact classes and describe the development of non-presence of teaching activity.

\section{Proyect}

This project aims to contribute to the development of ICT skills of the teachers of Higher Secondary Education of the Autonomous University of Nayarit, through a training program that involves the use of new technologies such as the transparent board (Crystalboard) for the creation own dynamic video tutorials; the editing and production of audio, sound and video for the creation of multimedia materials; the creation of interactive multimedia activities, such as crosswords, word searches, infographics, timelines, questionnaires, and more; as well as the design of activities and evaluations of the courses they teach with the help of a virtual learning environment.

The project has been planned in 3 stages: a) the first corresponds to a diagnosis to know the ICT skills that teachers have, b) the second corresponds to the training of teachers, and c) the third is about the implementation of resources , materials and strategies in upper secondary education students. 
It is important to note that to date only 2 stages have been completed, due to the health contingency the courses had to be taught remotely, which caused most of the teachers not to take the diploma, which had as a consequence that they did not a large enough sample will be considered compared to that of the diagnosis.

\section{Methodology}

\section{Stage 1}

As part of this stage, an instrument was applied to measure ICT skills in teachers. The criterion for selecting the sample was the total number of participants in the training course of the Higher Secondary Academic Units of the UAN in the northern zone. The instrument applied to the discussion groups consisted of 60 online questions. The type of study was mixed. In this research, the quantitative part is emphasized and contrasted with the qualitative results to achieve a better understanding. In total, 28 teachers participated. Of which, 16 belong to the female sex and 12 to the male.

The quantitative instrument was oriented to the identification of the learning scenarios. It comprises ten areas that focus on reviewing the characteristics of the discussion groups, which covered aspects of personal data, access to technological media, time spent on the Internet and the PC, information management, content management, communication, computer security, resolution problems, collaborative work and perception about ICT. For its part, the qualitative tool used was that of teaching discussion groups, belonging to each of the participating academic units.

\section{Stage 2}

At this stage, the results obtained from the surveys were analyzed to identify the strengths and weaknesses in the ICT competencies measured, with the aim of designing the courses to be taught and generating a diploma for registration with the Department of Teacher Development.

The diploma course was organized in 4 modules, each with a duration of 60 hours per module for a total of 240 hours of training, of which 120 would be face-to-face and 120 work on the platform; Due to the Sars Cov 2 health emergency, the planning was modified and it was taught completely remotely.
At the end of the training, an instrument will be applied to know the perception of the teachers regarding the courses. During the teaching of the courses, the high school teachers will carry out various activities to measure the knowledge and skills acquired in each subject taught.

At the end, the data and information obtained will be analyzed to present the results and obtain conclusions regarding the project carried out in the three high schools in the northern area of the State of Nayarit.

\section{Results}

The initial instrument (pre-test), applied to the discussion groups, was made up of ten items, covering aspects of personal data, access to technological means, time spent on the Internet and the PC, information management, content management, communication, computer security, problem solving, collaborative work and perception about ICT.

An analysis was carried out with information obtained through the instrument. that was applied to teachers of the preparatory academic units numbers 2, 9 and 12 of the UAN, 28 teachers participated, $43 \%$ were men and $57 \%$ women, in this study it is important to mention that $93 \%$ of the teachers have a bachelor's degree and the remaining $7 \%$ have a master's degree; On the other hand, $46 \%$ of the participants have an experience of 10 to 15 years of service in university teaching. The questions that evaluated the knowledge and use of ICT were structured with a 4-level Likert scale, where the lowest level is never, the second from time to time, the third regularly, and the fourth frequently.

Regarding technological means, it was found that $96 \%$ of teachers have their own computer and with which they can work their different learning units, $100 \%$ of teachers have internet in their homes, which facilitates work at home.

Regarding the time spent on the internet and using the computer, the results indicated that the majority of teachers seek information related to their profession, these responses reflect that $46 \%$ of the teachers interviewed seek information related to their work or their matter from 30 to 60 minutes a day and $43 \%$ use it for more than 60 minutes. 
Speaking of the area of perception about ICT, $90 \%$ of teachers think that ICT have come to improve the environment and teaching activity, some consider that it generates a distance with those who do not have access to this type of technology. $100 \%$ of the teachers surveyed are willing to make use of ICT in the professional field as part of an update and strategies to carry out their teaching performance. At the same time, they mentioned that a good teacher should consider knowing and mastering ICT to support and teach their learning units.

Regarding the teachers who took the distance diploma, it is necessary that of the 17 teachers who started it, 16 ended it by completing most of the activities, which is equivalent to $94 \%$. In total, 17 activities were carried out by the high school teachers to demonstrate the learning of the tools and applications. However, if compared with the teachers who answered the survey to measure ICT skills, only $27 \%$ took it.

Once the diploma course was completed, a questionnaire was applied to them to measure again the degree of knowledge and use, as well as to know their impressions in relation to the themes and the modality. When analyzing the results, it was found that from the Pre-test to the Post-Test, there was a significant improvement, which can be seen in the following table.

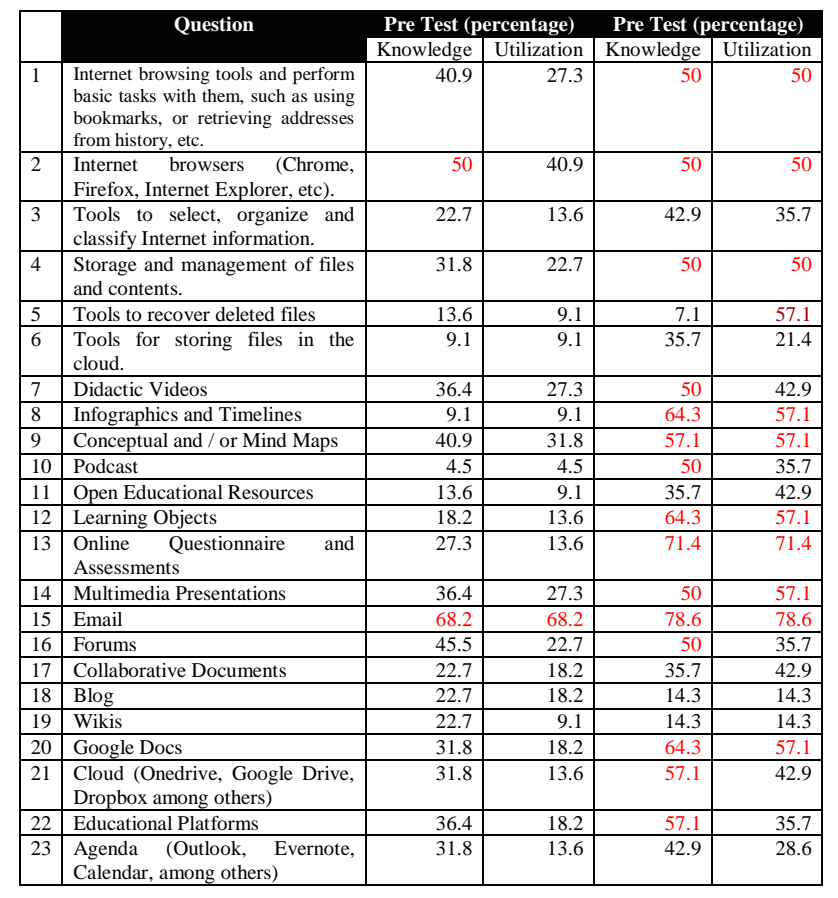

Table 1 Table of frequencies of level 4 of the questionnaire applied to high school teachers
When analyzing the results obtained in both questionnaires, a great change is observed in the attitude of teachers regarding the use of ICT in their teaching process, since only in the use of blogs there was a decrease in its application as didactic tools by teachers. This means that $96 \%$ effectiveness was achieved in achieving the objectives set for the diploma.

Regarding the general use of navigation tools and Internet browsers, it did not show significant changes, there was a lot of progress in the use of tools for selecting, organizing and classifying information with more than $250 \%$. The most significant changes are observed in the use of applications as didactic support in the teacher's teaching process, such as the use of video with $157 \%$ progress, infographics and timelines with $627 \%$ progress, the use of concept maps $80 \%$ complete, podcast use increased by almost $800 \%$, this being the fastest growing, ODT use increased by more than $400 \%$, use of online questionnaires and evaluations increased more $500 \%$ and collaborative documents more than $200 \%$. These advances were the most significant when observing the advantages implied by its use by the teacher.

Among the comments that were collected in the final evaluation to the question of what did you think of the diploma? Are: "Excellent, it was received at the most appropriate time and the panorama for the new normal that is coming. $100 \%$ productive", "Excellent!!! The truth is I learned many tools to work online and remotely. Everything we saw in the diploma is $100 \%$ applicable to our classes, with this diploma I realized that academically everything is possible, even the classes of experimental sciences "," I think that, due to contingency and real needs, are the appropriate content to develop teaching skills". And in relation to the question, What did you think of working in Distance mode?, The teachers said: "At first with a bit of uncertainty but later it was comfortable", "Practical, complementary and I think it can be more productive than face-to-face, due to the level of research that requires the student to be able to solve the assignments or activities "," At first it was difficult for me to adapt, but later I realized that working remotely is easy and I liked it because of the comfort in a matter of time, since you get organized and everything becomes easier ", "In general, a pleasant experience and above all, that the tools and knowledge acquired are put into practice and are very useful. 
However, I think having a teacher personally gives us a sense of more human warmth and security. ".

\section{Discussion}

Based on the results obtained, it is important to point out that teachers know many of the ICTs that are applied to education, however, when asked about their use, the percentage decreases considerably. Whether they are asked about information management, content management, the use of applications and ICT resources, the majority have answered that they do not use them, they only know them.

An interesting fact that has come to light is the fact that the vast majority have a computer and internet at home, which represents a great opportunity to take advantage of ICT in the classroom and in teaching. Regarding the use they make of the computer connected to the internet at home, they have answered that they use it to search for information, watch videos and read academic topics, which is important so that once they know new tools and applications, they acquire ICT skills that allows them to improve the use of the PC and the internet for the benefit of students.

The questions that were asked in relation to communication, in the pre-test and post-test, show that teachers currently make constant use of synchronous and asynchronous communication applications, such as WhatsApp, Facebook Messenger and Email Electronic. However, the use of forums, blogs and wikis is not a common practice of upper secondary teachers.

One of the categories that have attracted the most attention is that of applications and resources for collaborative work. Their knowledge and use of them is very low, which reflects the lack of ICT skills in this regard, and which leads to the lack of creation of collaborative activities with students. To a certain extent it is understandable, because the modality of the surveyed high schools is face-toface, and therefore, the use of collaborative tools is not essential, since these activities are carried out in the classroom. However, once they were trained, they used them constantly.

\section{Conclusions}

From the 2 completed stages of the project, it can be affirmed that ICT applied to education is currently important in order to offer diversity and versatility in classes. In this sense, the teachers who took the online diploma course have stated that they have liked the content covered in the course, and that they are willing to continue training in the use and application of educational technology tools.

For the work team it has been a very enriching experience, because the distance modality was approached without planning it with the teachers who took the diploma. The fact of not being prepared for the Distance mode resulted in more work being done than expected in order to adapt the activities to the new mode. The health contingency that is experienced has resulted in teachers being encouraged to train in educational technology in order to use an educational platform as the axis in the organization and administration of the content to be taught. Likewise, it is important to recognize the professors who took the diploma, as they unexpectedly prepared for the health contingency.

It is expected that in the near future the project to measure learning and to know the perception and motivation of students when using technological tools and applications in their learning process can be concluded. To evaluate the results, it is necessary to train more teachers and apply what they have learned to carry out an information gathering with the students.

Finally, it can be concluded that the training of teachers in educational technology is increasingly necessary to be prepared for any situation that arises and forces them to teach at a distance. In this sense, it can be said that knowledge in educational technology and the development of ICT skills in teachers has become essential, now more than ever, and it is not known what the future holds, so it is better to be prepared. 


\section{References}

Bauer, J. y J. Kenton (2005), "Toward technology integration in the schools: Why it isn't happening" [version electronica], Journal of Technology and Teacher Education, 13:519$546 . \quad$ Recuperado de: https://pdfs.semanticscholar.org/49f9/eed2b61c d2bc0fe7553194e77fdddb932def.pdf?_ga=2.12 0625800.1411945517.16091951141645271681.1609195114

Comisión Económica para América Latina y el Caribe (2020). América Latina y el Caribe ante la pandemia del COVID-19. Efectos económicos $y$ sociales. Recuperado de https://repositorio.cepal.org/bitstream/handle/11 362/45337/4/S2000264_es.pdf

Cuban, L., H. Krikpatrick y C. Peck (2001), "High access and low use of technologies in high school classrooms: Explaining an apparent paradox" [version electrónica], American Educational Research Journal, 38: 813-834. https://doi.org/10.3102/00028312038004813

Kozma, R. B. (2003), "Technology and classroom practices: An international study" [versión electrónica], Journal of Research on Technology in Education, 36: 114.

Organización Mundial de la Salud (2020). Alocución de apertura del Director General de la OMS en la rueda de prensa sobre la COVID-19. Recuperado de https://www.who.int/es/dg/speeches/detail/whodirector-general-s-openingremarks-at-themedia-briefing-on-covid-19---11-march-2020

Organización Panamericana de la SaludOrganización Mundial de la Salud OPS-OMS (2020). Actualización Epidemiológica Nuevo coronavirus (COVID-19). Recuperado de https://www.paho.org/sites/default/files/202002/2020-feb-28- phe-actualizacion-epicovid19.pdf

Robertson, J. W. (2003), "Stepping out of the box: Rethinking the failure of ICT to transform schools" [versión electrónica], Journal of Educational Change, 4: 323-344.UNESCO (2020a). Coalición Mundial para la Educación COVID-19. Disponible en https://es.unesco.org/covid19/globaleducationc oalition
UNESCO. (2016). Academia. Recuperado de: http://www.un.org/es/sections/resources/acade mia/index.html.

UNESCO (2020b). Diez recomendaciones para estudiar a distancia durante la emergencia del coronavirus. Recuperado de https://news.un.org/es/story/2020/03/14713421 6

World Vision Internacional (2020). Consecuencias del COVID-19. Las repercusiones secundarias ponen en más riesgo las vidas de los niños que la propia enfermedad Recuperado de https://www.wvi.org/sites/default/files/202004/CONSECUENCIAS\%20DEL\%20COVID1 9\%20LAS\%20REPERCUSIONES\%20SECUN DARIAS \%20PONEN\%20EN\%20M\%C3\%81S \%20RIESGO $\% 20$ LAS $\% 20$ VIDAS $\% 20$ DE $\% 20$ LOS $\% 20 \mathrm{NI} \% \mathrm{C} 3 \%$ 91OS\%20QUE\%20LA\%20 PROPIA\%20ENFERMEDA.pdf 